\title{
KAT6A/NCOA2 Fusion Gene
}

National Cancer Institute

\section{Source}

National Cancer Institute. KAT6A/NCOA2 Fusion Gene. NCI Thesaurus. Code C99499.

A fusion gene that results from a chromosomal inversion inv(8)(p11q13) which fuses the 5' portion of the KAT6A gene to the 3' portion of the NCOA2 gene. This rearrang ement is associated with acute myeloid leukemia. 